\title{
REVIEW
}

\section{Enhancing intervertebral disc repair and regeneration through biology: platelet-rich plasma as an alternative strategy}

\author{
Shan-Zheng Wang ${ }^{1+}$, Yun-Feng Rui ${ }^{1 *}$, Qi Tan ${ }^{2}$ and Chen Wang ${ }^{1 *}$
}

\begin{abstract}
Intervertebral disc degeneration (IDD) is a common orthopedic disease associated with mechanical changes that may result in significant pain. Current treatments for IDD mainly depend on conservative therapies and spinal surgeries that are only able to relieve the symptoms but do not address the cause of the degeneration and even accelerate the degeneration of adjacent segments. This has prompted research to improve our understanding of the biology of intervertebral disc healing and into methods to enhance the regenerative process. Recently, biological therapies, including active substances, gene therapy and tissue engineering based on certain cells, have been attracting more attention in the field of intervertebral disc repair and regeneration. Early selection of suitable biological treatment is an ideal way to prevent or even reverse the progressive trend of IDD. Growth factors have been enjoying more popularity in the field of regeneration of IDD and many have been proved to be effective in reversing the degenerative trend of the intervertebral disc. Identification of these growth factors has led to strategies to deliver platelet-derived factors to the intervertebral disc for regeneration. Platelet-rich plasma (PRP) is the latest technique to be evaluated for promoting intervertebral disc healing. Activation of the PRP leads to the release of growth factors from the a-granules in the platelet cytoplasm. These growth factors have been associated with the initiation of a healing cascade that leads to cellular chemotaxis, angiogenesis, synthesis of collagen matrix, and cell proliferation. This review describes the current understanding of IDD and related biological therapeutic strategies, especially the promising prospects of PRP treatment. Future limitations and perspectives of PRP therapy for IDD are also discussed.
\end{abstract}

\section{Introduction}

Intervertebral disc degeneration (IDD) is considered to be one of the strongly associated causes of lower back pain and related diseases of the spine, which exert a high cost on society [1,2]. It is well known, however, that the intervertebral disc is an avascular tissue that has limited capacity for regeneration. This has prompted research to improve our understanding of the biology of intervertebral disc healing and into methods to enhance the regenerative process. Recently, biological treatments for early intervention have been introduced and developed, including the application of active substances, gene therapy and tissue engineering based on stem cells. These

\footnotetext{
* Correspondence: yfrui@seu.edu.cn; wangchen@medmail.com.cn ${ }^{\dagger}$ Equal contributors

'Department of Orthopaedics, Zhongda Hospital, Medical School of Southeast University, 87 Ding Jia Qiao Road, Nanjing, Jiangsu 210009, China Full list of author information is available at the end of the article
}

treatments have been reported to promote intervertebral disc regeneration by upregulating the synthesis of extracellular matrix and the metabolism of the intervertebral discs, further shedding light on the reversal and repair of IDD $[3,4]$.

The most direct therapeutic strategy for reversing IDD is the injection of active substances, mainly including multiple biologically active growth factors. As it contains high concentrations of platelets, which can release various kinds of multifunctional growth factors when activated (Table 1), platelet-rich plasma (PRP) represents a new strategy for the biological treatment of IDD [5]. Current studies have indicated that a variety of cytokines applied in the early stage of IDD could lead to a good outcome, as a large number of phenotypically stable cells are still present and could still react to these cytokines in the early degenerated discs. In addition, the combined 
Table 1 Growth factors identified within platelet-rich plasma and their biological functions

\begin{tabular}{|c|c|c|}
\hline Name & Abbreviation & Function \\
\hline $\begin{array}{l}\text { Platelet-derived growth } \\
\text { factor }\end{array}$ & PDGF & $\begin{array}{l}\text { Stimulation of fibroblast production, chemotaxis, transforming growth factor- } \beta 1 \text {, collagen production; } \\
\text { upregulation of proteoglycan synthesis of fibroblasts, smooth muscle cells, chondrocytes, osteoblasts and } \\
\text { mesenchymal stem cells }\end{array}$ \\
\hline $\begin{array}{l}\text { Insulin-like growth } \\
\text { factor-1 }\end{array}$ & IGF1 & $\begin{array}{l}\text { Promotion of cell growth, differentiation, recruitment in bone, blood vessel, skin, other tissues; } \\
\text { upregulation of collagen synthesis with PDGF of fibroblasts }\end{array}$ \\
\hline $\begin{array}{l}\text { Transforming growth } \\
\text { factor-beta } 1\end{array}$ & TGF- $\beta 1$ & $\begin{array}{l}\text { Promotion of fibroblast proliferation, extracellular matrix formation, cell viability, production of collagen } \\
\text { from fibroblasts; suppressed interleukin 1-mediated effects on proteoglycan synthesis in cartilage }\end{array}$ \\
\hline $\begin{array}{l}\text { Vascular endothelial } \\
\text { growth factor }\end{array}$ & VEGF & $\begin{array}{l}\text { Promotion of cell growth, migration, new blood vessel growth and anti-apoptosis (anti-cell death) of } \\
\text { blood vessel cells }\end{array}$ \\
\hline $\begin{array}{l}\text { Basic fibroblastic growth } \\
\text { factor }\end{array}$ & bFGF & Stimulation of collagen production, angiogenesis and myoblast proliferation \\
\hline Epidermal growth factor & EGF & $\begin{array}{l}\text { Promotion of cell recruitment, proliferation, differentiation, angiogenesis, cytokine secretion by } \\
\text { mesenchymal and epithelial cells }\end{array}$ \\
\hline $\begin{array}{l}\text { Connective tissue } \\
\text { growth factor }\end{array}$ & CTGF & Promotion of angiogenesis, cartilage regeneration, fibrosis, platelet adhesion \\
\hline
\end{tabular}

In view of the multiple biologically active growth factors stored in platelets, the table presents a broad but also far from complete view of the effects of the growth factors.

application of multiple cytokines released from PRP will contribute to synergistic effects. This review explores the current biological therapeutic strategies for IDD and PRP as an autologous blood product used in the treatment of IDD. This survey and discussion might serve as a source of information to aid future applications of PRP and the design of appropriate biological strategies for treating human IDD.

\section{What is intervertebral disc degeneration?}

IDD is perhaps best defined as a cascade that begins with changes to the cellular microenvironment and progresses to the structural breakdown and functional impairment of the intervertebral disc [6]. Aging, living conditions, biomechanical loading and genetic factors are often related to disc degeneration $[7,8]$. Prominent changes occurring during IDD are characterized by a decrease of active cell numbers, depletion of extracellular matrix, altered phenotype of normal disc cells, and the presence of pro-inflammatory cytokines and mediators $[9,10]$. These cellular and molecular changes greatly influence the progression of IDD, which further impairs the biological and mechanical function of the intervertebral disc and patients' quality of life.

\section{Current clinical treatments for intervertebral disc degeneration and their limitations}

Current therapeutic strategies for treating IDD are primarily conservative, including physiotherapy and anti-inflammatory medications. Spinal surgery, mainly including discectomy, interbody fusion and disc replacement, are the current gold standard to alleviate symptoms of IDD, but the adjacent spine may experience a high risk of accelerated degeneration [11]. Therefore, the choice of an effective treatment for IDD with minimal adverse effects on individuals is particularly important to prevent the degenerative trend of IDD and relieve pain in patients.

\section{Current status of biological treatments for intervertebral disc degeneration}

With our improving understanding of the importance of the molecular and cellular mechanisms of IDD, biological treatments are attracting more attention $[12,13]$. Promising biological treatments predominantly consist of direct injection of active substances, gene therapy and tissue engineering based on certain cells.

Direct injection of active substances could stimulate the proliferation of intervertebral disc cells and the accumulation of extracellular matrix [14], which could slow or even reverse the degenerative trend of IDD. However, the short half-life of active substances hinders the effectiveness of this therapy. So the ideal approach is to transfect intervertebral disc cells with genes encoding the active proteins so that these cells could stably produce the corresponding bioactive products, thus upregulating the synthesis of extracellular matrix in a gradual way. Tissue engineering using cells, especially stem cells, is based on the fact that the increase in active cells within the intervertebral disc will gradually restore its structural integrity and function; many studies have confirmed the efficacy of this procedure [15-17]. Carriers or scaffolds of stem cells with good bio-compatibility are currently being developed with promising prospects.

However, studies on biological treatments for IDD have so far mostly been restricted to in vitro studies and animal experiments, and clinical application is still a long way in the future. According to current experimental results, biological treatments hold broad prospects for preventing or even reversing the progression of IDD. 


\section{Biological and pathological characteristics of intervertebral disc degeneration: the importance of and opportunities for early interventions}

With the lack of nutrient diffusion through the cartilaginous endplate, degenerated intervertebral discs may undergo a gradual decrease in active cell numbers [18]. Also, the degenerative process of the intervertebral disc is significantly related to the loss of proteoglycan, which further lowers the osmotic pressure of the internal environment and renders the degenerated disc unable to maintain hydration under load [19]. Although collagen content decreases with the progression of IDD, this is not significant compared to that of proteoglycans. However, a shift in the balance of collagen types and their distribution may occur. The decrease in collagen content and the shift from type II to type I collagen contribute to fibrosis of the nucleus pulpous [20]. With the fusion of the nucleus pulposus and annulus fibrosis, the difference between the two becomes less obvious.

IDD is a progressive, chronic disease. Over time, the degeneration worsens and ultimately becomes irreversible, so early biological intervention is important to reverse the trend of degeneration [21]. In the late stage of IDD, the calcified cartilage endplates (CEPs) hold limited potential for vascularization and nutrient delivery. Early intervention during disc degeneration has many advantages because many viable cells are still retained and cellular phenotypic changes are few. So the injection of active substances is potent enough to stimulate restoration during the early stage of degeneration. Early in IDD, single or multiple injections of biologically active substances, especially growth factors, could effectively regulate the metabolic balance of the extracellular matrix and maintain the homeostasis of the intervertebral disc [22]. Gene therapy $[23,24]$ and tissue engineering based on stem cells $[25,26]$ are possible alternative choices for IDD therapy. Gene therapy could prolong the duration of expression of active substances but the efficacy of clinical application and safety issues have not yet been determined. Tissue engineering based on cells requires a high standard of clinical research, complicated culture conditions, as well as complex surgical procedures. Meanwhile, the existence of immune rejection, tumorigenicity of the transplanted cells, and unexpected outcomes restrict the prospects for their clinical application. Therefore, the ideal solution to prevent or even reverse the degenerative trend of IDD is intervention using active substances in the early stage of IDD.

\section{Effects of platelet-rich plasma growth factors on intervertebral disc degeneration: in vitro and in vivo studies}

The injection of active substances is more suitable for early intervention in IDD compared with other therapies. Stimulation from active substances, especially the cytokines or growth factors present in PRP, maintains intervertebral disc homeostasis by shifting cellular catabolism to the anabolic state [27]. The clinical injection of active substances can be carried out under fluoroscopic guidance and is less invasive than spinal surgeries, especially for multi-segment disc degeneration, reducing injury to a minimum level.

Many in vivo and in vitro studies have been conducted using multiple growth factors present in PRP to stimulate the proliferation of intervertebral disc cells with promising results (Table 2). Transforming growth factor (TGF)- $\beta 1$ is one of the early morphogenic molecules studied in vitro to promote the synthesis of proteoglycans $[28,29]$. Gruber and colleagues [30] reported that TGF- $\beta 1$ could effectively stimulate the proliferation of human annulus fibrosus cells after 4 days exposure. Lee and colleagues [31] confirmed the proliferative effect of TGF- $\beta 1$ when culturing rabbit nucleus pulposus cells seeded in atelocollagen scaffolds under the stimulation of TGF- $\beta 1$. Insulin-like growth factor (IGF)-1 has a similar function as it promotes cell proliferation and matrix synthesis in vitro [32]. A study from Hayes and Ralphs [33] confirmed that TGF- $\beta 1$ and IGF-1, both alone and in combination, could effectively stimulate the synthesis of sulfated glycosaminoglycan and collagen types I and II by annulus cells. Further, these authors proved the potential role of TGF-1 in pushing cells towards a fibrocartilaginous phenotype, with possible complementary effects of IGF-1. In addition, IGF-1 and platelet-derived growth factor (PDGF) were both reported to be able to reduce the percentage of apoptotic annulus fibrosus cells [34]. However, another study indicated that TGF- $\beta$ was superior to epidermal growth factor (EGF), IGF-1, PDGF and fibroblastic growth factor (FGF) in upregulating the synthesis of proteoglycan [32].

In an in vitro culture system, Pratsinis and Kletsas [35] reported that PDGF, basic FGF (bFGF) and IGF-I could all effectively stimulate the proliferation of intervertebral disc cells obtained from bovine coccygeal tissues, and PDGF was the most potent mitogen among these. Vascular endothelial growth factor (VEGF)-A functions in nucleus pulposus survival as it has strong angiogenic activity and specific mitogenic and chemotactic actions [36]. In a gene transfection study, Liu and colleagues [37] reported that the increased connective tissue growth factor (CTGF) expression resulting from transfecting rAAV2-CTGF into Rhesus monkey lumbar nucleus pulposus cells enhanced collagen type II protein and proteoglycan synthesis. In a degenerative murine caudal disc compression model, Walsh and colleagues [38] compared the effects of single and multiple injections of a variety of growth factors, including growth and differentiation factor (GDF)-5, TGF- $\beta$, IGF-1, and 
Table 2 The in vitro and in vivo influence of growth factors present in platelet-rich plasma

\begin{tabular}{|c|c|c|c|c|c|c|c|}
\hline $\begin{array}{l}\text { Growth } \\
\text { factor }\end{array}$ & Dose & Species & $\begin{array}{l}\text { Target cell type/ } \\
\text { tissue/animal } \\
\text { model }\end{array}$ & $\begin{array}{l}\text { Cellular } \\
\text { scaffold }\end{array}$ & Outcome & Study & Year \\
\hline \multicolumn{8}{|l|}{ In vitro } \\
\hline \multirow[t]{2}{*}{ PDGF } & $100 \mathrm{ng} / \mathrm{ml}$ & Human & $\begin{array}{l}\text { Annulus fibrosus } \\
\text { cells }\end{array}$ & None & $\begin{array}{l}\text { Significant reduction in the percentage of apoptotic } \\
\text { cells }\end{array}$ & $\begin{array}{l}\text { Gruber } \\
\text { et al. [30] }\end{array}$ & 1997 \\
\hline & $\begin{array}{l}1-20 \mathrm{ng} / \\
\mathrm{ml}\end{array}$ & Bovine & $\begin{array}{l}\text { Coccygeal nucleus } \\
\text { pulposus and } \\
\text { annulus fibrosus } \\
\text { cells }\end{array}$ & None & Improved proliferation & $\begin{array}{l}\text { Pratsinis } \\
\text { and Kletsas } \\
\text { [35] }\end{array}$ & 2007 \\
\hline \multirow[t]{5}{*}{ IGF1 } & $20 \mathrm{ng} / \mathrm{ml}$ & $\begin{array}{l}\text { Mature } \\
\text { canine }\end{array}$ & $\begin{array}{l}\text { Intervertebral disc } \\
\text { tissues }\end{array}$ & None & Increased matrix synthesis and cell proliferation & $\begin{array}{l}\text { Thompson } \\
\text { et al. [32] }\end{array}$ & 1991 \\
\hline & $\begin{array}{l}1-1,000 \\
\mathrm{ng} / \mathrm{ml}\end{array}$ & Bovine & $\begin{array}{l}\text { Nucleus pulposus } \\
\text { cells }\end{array}$ & None & Increased proteoglycan synthesis & $\begin{array}{l}\text { Osada } \\
\text { et al. [29] }\end{array}$ & 1996 \\
\hline & $\begin{array}{l}20-500 \mathrm{ng} / \\
\mathrm{ml}\end{array}$ & Human & $\begin{array}{l}\text { Annulus fibrosus } \\
\text { cells }\end{array}$ & None & $\begin{array}{l}\text { Significant reduction in the percentage of apoptotic } \\
\text { cells }\end{array}$ & $\begin{array}{l}\text { Gruber } \\
\text { et al. [34] }\end{array}$ & 2000 \\
\hline & $\begin{array}{l}5-200 \mathrm{ng} / \\
\mathrm{ml}\end{array}$ & Bovine & $\begin{array}{l}\text { Coccygeal nucleus } \\
\text { pulposus and } \\
\text { annulus fibrosus } \\
\text { cells }\end{array}$ & None & Improved proliferation & $\begin{array}{l}\text { Pratsinis } \\
\text { and Kletsas } \\
\text { [35] }\end{array}$ & 2007 \\
\hline & $5 \mathrm{ng} / \mathrm{ml}$ & E19 rat & $\begin{array}{l}\text { Annulus fibrosus } \\
\text { cells }\end{array}$ & None & Upregulation of extracellular matrix & $\begin{array}{l}\text { Hayes et al. } \\
{[33]}\end{array}$ & 2011 \\
\hline \multirow[t]{3}{*}{ TGF- $\beta 1$} & $1 \mathrm{ng} / \mathrm{ml}$ & $\begin{array}{l}\text { Mature } \\
\text { canine }\end{array}$ & $\begin{array}{l}\text { Intervertebral disc } \\
\text { tissues }\end{array}$ & None & Increased matrix synthesis and cell proliferation & $\begin{array}{l}\text { Thompson } \\
\text { et al. [32] }\end{array}$ & 1991 \\
\hline & $5 \mathrm{ng} / \mathrm{ml}$ & E19 rat & $\begin{array}{l}\text { Annulus fibrosus } \\
\text { cells }\end{array}$ & None & Pushed cells towards a fibrocartilaginous phenotype & $\begin{array}{l}\text { Hayes and } \\
\text { Ralphs [33] }\end{array}$ & 2011 \\
\hline & $10 \mathrm{ng} / \mathrm{ml}$ & Rabbit & $\begin{array}{l}\text { Nucleus pulposus } \\
\text { cells }\end{array}$ & Atelocollagen & Robust refurbishment of matrix & $\begin{array}{l}\text { Lee et al. } \\
\text { [31] }\end{array}$ & 2012 \\
\hline VEGF & $\begin{array}{l}\text { Not } \\
\text { mentioned }\end{array}$ & $\begin{array}{l}\text { Vegfr-1lacZ/+ } \\
\text { and Vegfr- } \\
2 \text { lacZ/+ } \\
\text { mouse }\end{array}$ & $\begin{array}{l}\text { Nucleus pulposus } \\
\text { cells }\end{array}$ & None & Promotion of nucleus pulposus survival & $\begin{array}{l}\text { Fujita et al. } \\
{[36]}\end{array}$ & 2008 \\
\hline \multirow[t]{2}{*}{ bFGF } & $300 \mathrm{ng} / \mathrm{ml}$ & $\begin{array}{l}\text { Mature } \\
\text { canine }\end{array}$ & $\begin{array}{l}\text { Intervertebral disc } \\
\text { tissues }\end{array}$ & None & Increased matrix synthesis and cell proliferation & $\begin{array}{l}\text { Thompson } \\
\text { et al. [32] }\end{array}$ & 1991 \\
\hline & $\begin{array}{l}0.1-20 \mathrm{ng} / \\
\mathrm{ml}\end{array}$ & Bovine & $\begin{array}{l}\text { Coccygeal nucleus } \\
\text { pulposus and } \\
\text { annulus fibrosus } \\
\text { cells }\end{array}$ & None & Enhanced proliferation & $\begin{array}{l}\text { Pratsinis } \\
\text { and Kletsas } \\
{[35]}\end{array}$ & 2007 \\
\hline EGF & $1 \mathrm{ng} / \mathrm{ml}$ & $\begin{array}{l}\text { Mature } \\
\text { canine }\end{array}$ & $\begin{array}{l}\text { Intervertebral disc } \\
\text { tissues }\end{array}$ & None & Enhanced proliferation & $\begin{array}{l}\text { Thompson } \\
\text { et al. [32] }\end{array}$ & 1991 \\
\hline CTGF & $\begin{array}{l}\text { Not } \\
\text { mentioned }\end{array}$ & $\begin{array}{l}\text { Rhesus } \\
\text { monkey }\end{array}$ & $\begin{array}{l}\text { Lumbar } \\
\text { intervertebral disc } \\
\text { nucleus pulposus } \\
\text { cells }\end{array}$ & None & Enhanced synthesis of proteoglycan and collagen II & $\begin{array}{l}\text { Liu et al. } \\
{[37]}\end{array}$ & 2010 \\
\hline \multicolumn{8}{|l|}{ In vivo } \\
\hline IGF1 & $\begin{array}{l}8 \mathrm{ng} / 8 \mathrm{ul} / \\
\mathrm{disc}\end{array}$ & $\begin{array}{l}\text { Male Swiss } \\
\text { Webster } \\
\text { mouse }\end{array}$ & $\begin{array}{l}\text { Caudal disc } \\
\text { compression } \\
\text { model }\end{array}$ & None & $\begin{array}{l}\text { An upward trend of cell density, but not statistically } \\
\text { significant (single injection); a trend of increased disc } \\
\text { height, but also not statistically significant (multiple } \\
\text { injections) }\end{array}$ & $\begin{array}{l}\text { Walsh et al. } \\
\text { [38] }\end{array}$ & 2004 \\
\hline TGF- $\beta 1$ & $\begin{array}{l}1.6 \mathrm{ng} / 8 \\
\mu \mathrm{l} / \mathrm{disc}\end{array}$ & $\begin{array}{l}\text { Male Swiss } \\
\text { Webster } \\
\text { mouse }\end{array}$ & $\begin{array}{l}\text { Caudal disc } \\
\text { compression } \\
\text { model }\end{array}$ & None & $\begin{array}{l}\text { A greater percentage of proliferating cells, but not } \\
\text { statistically significant (single injection); increased } \\
\text { population of anular fibrochondrocytes (multiple } \\
\text { injections) }\end{array}$ & $\begin{array}{l}\text { Walsh et al. } \\
\text { [38] }\end{array}$ & 2004 \\
\hline bFGF & $\begin{array}{l}8 \mathrm{ng} / 8 \mu \mathrm{l} / \\
\mathrm{disc}\end{array}$ & $\begin{array}{l}\text { Male Swiss } \\
\text { Webster } \\
\text { mouse }\end{array}$ & $\begin{array}{l}\text { Caudal disc } \\
\text { compression } \\
\text { model }\end{array}$ & None & $\begin{array}{l}\text { An upward trend of cell density, but not statistically } \\
\text { significant (single injection) }\end{array}$ & $\begin{array}{l}\text { Walsh et al. } \\
{[38]}\end{array}$ & 2004 \\
\hline
\end{tabular}

The growth factors listed are stored in platelets and have exhibited promising potential in the regeneration of degenerated discs, indicating the potential of platelet-rich plasma therapy. $b F G F$, basic fibroblastic growth factor; $C T G F$, connective tissue growth factor; EGF, epidermal growth factor; GDF, growth and differentiation factor; IGF, insulin-like growth factor; PDGF, platelet-derived growth factor; TGF, transforming growth factor; VEGF, vascular endothelial growth factor. 
bFGF; GDF- 5 and TGF- $\beta$ induced the expansion of the inner annulus fibrosus fibrochondrocyte populations into the nucleus pulposus and upregulated the expression of aggrecan and type II collagen, while IGF-1 yielded a transient proliferative effect. The authors thus concluded that early intervention during disc degeneration had implications for the arrest or slowing of the degenerative process.

Given the interactions of growth factors that are necessary for proper intervertebral disc homeostasis and regeneration, it is unlikely that any single growth factor will alone enable the repair of IDD, but rather a combination of multiple growth factors will be needed. Based on the concept that a combination approach is necessary for disc regeneration, recent attention has turned to PRP.

\section{Platelet-rich plasma as a strategy for intervertebral disc degeneration repair and regeneration}

PRP can be defined as a volume of autologous plasma with the platelet concentration above baseline [39]. PRP has been clinically applied for its healing properties [40], and now is widely applied in many therapeutic areas. The concept that PRP application would promote IDD regeneration is based on the role of platelets in wound healing. When activated, platelets can secrete a variety of growth factors, including PDGF, IGF-1, TGF- $\beta$, VEGF, bFGF, EGF, and CTGF, among others [41,42]. All these growth factors might play significant roles in promoting the proliferation of tissues. Platelets also contain antibacterial and bactericidal proteins that may influence the process of inflammatory responses by inducing the synthesis of some molecules, such as integrins, interleukins and chemokines [43]. Last but not least, platelets may serve as a biological sponge because they can absorb, store and transfer some small molecules that regulate tissue regeneration [44]. PRP represents a new biotechnology in tissue engineering and has become a popular clinical treatment for various tissue healing applications without any immune rejections.

Compared with other bioactive peptides or growth factors, however, PRP is limited in its clinical application mainly because of its autologous origin. If the physical condition of a patient renders them unsuitable for generating PRP, such as patients with hematologic diseases, then PRP will not be an ideal therapy for IDD. Modern biotechnology has greatly increased our knowledge about the gene sequences and receptors of many bioactive substances and although artificially synthesized growth factors are more costly with short half-lives, they are convenient and their application is not restrained by the physical condition of the patient.

Compared with other bioactive factors, PRP is rather a good choice for patients qualified for PRP preparations.
Unlike other bioactive factors with complicated or unstable properties used for the clinical treatment of damaged tissues, PRP can be quickly obtained in the operating room by centrifugation of the patient's own blood and directly applied to target tissues. Also, from the viewpoint of clinical application, autologous PRP avoids complex regulations, disease transmission and immunologic reactions [45].

PRP injection into degenerated intervertebral discs is currently a relatively less invasive and convenient therapeutic procedure compared to other options. However, needle puncture could induce cell death and degeneration of discs [46-48], so needles of smaller size and the fewest numbers of injections possible are beneficial for clinical patients. To the best of our knowledge, no clinical studies have so far indicated the number of injections required. Some preclinical studies have indicated that a single injection of PRP in the degenerated discs of animal models was effective to help restore disc height and water content [46-48]. Gullung and colleagues [46] confirmed that a single injection of PRP into the degenerated discs of Sprague-Dawley rats was effective for maintaining fluid content on magnetic resonance imaging (MRI). Obata and colleagues $[47,48]$ proved that a single intra-discal injection of PRP serum was potent enough to restore disc height and induce cell proliferation in a rabbit IDD model. In our previous animal study, which established an early IDD model, a single injection of PRP was effective for IDD regeneration [49].

Considering these animal studies, we propose that a single injection using smaller needles at the right time, especially in the early stage of IDD, might be sufficient for clinical applications. However, more clinical studies are needed in the future to confirm this.

\section{Current evidence for the efficacy of platelet-rich plasma therapy in intervertebral disc degeneration}

PRP contains a variety of proteins and growth factors that are expected to serve as a therapeutic growth factor cocktail, playing a pivotal role in regulating the tissue microenvironment, improving cellular functions and promoting the regeneration of damaged tissues. Many in vivo and in vitro studies have confirmed the efficacy of PRP in IDD treatment (Table 3).

Chen and colleagues [50] demonstrated that PRP might be a therapeutic candidate for the prevention of IDD by culturing intervertebral disc cells together with PRP. Subsequently, Chen and colleagues [51] introduced a novel intervertebral disc organ culture system to study a PRP-based therapeutic approach for the amelioration of IDD. Their results indicated that PRP could promote nucleus pulposus regeneration and resulted in significantly increased levels of mRNAs involved in chondrogenesis and matrix accumulation; moreover, the disc 
Table 3 In vitro and in vivo effects of platelet-rich plasma on intervertebral disc regeneration

\begin{tabular}{|c|c|c|c|c|c|c|}
\hline Activator & $\begin{array}{l}\text { System used to obtain } \\
\text { PRP }\end{array}$ & $\begin{array}{l}\text { Cell } \\
\text { scaffold }\end{array}$ & PRP carriers & Results & Authors & Year \\
\hline $\begin{array}{l}10 \% \text { thrombin solution } \\
(\mathrm{vol} / \mathrm{vol}, 1,000 \mathrm{U} / \mathrm{ml} \text { in } \\
\left.100 \mathrm{mmol} / \mathrm{I} \mathrm{CaCl}_{2}\right)\end{array}$ & $\begin{array}{l}\text { SYMPHONY } 2 \text { Platelet } \\
\text { Concentration System } \\
\text { (DePuy Spine, Raynham, MA, } \\
\text { USA) }\end{array}$ & $\begin{array}{l}\text { Alginate } \\
\text { beads }\end{array}$ & None & $\begin{array}{l}\text { Increased accumulation of glycosaminoglycan; } \\
\text { upregulated mRNA expression of Sox9, type II } \\
\text { collagen, and aggrecan }\end{array}$ & $\begin{array}{l}\text { Akeda } \\
\text { et al. [52] }\end{array}$ & 2006 \\
\hline $\begin{array}{l}\text { Bovine thrombin ( } 100 \\
\text { IU bovine thrombin/ } \\
150 \mathrm{ml} \mathrm{PRP)}\end{array}$ & $\begin{array}{l}\text { MSC blood cell separation } \\
\text { system (Haemonetics Corp., } \\
\text { Braintree, MA, USA) }\end{array}$ & None & None & $\begin{array}{l}\text { Induction of human nucleus pulposus } \\
\text { proliferation and chondrogenic differentiation }\end{array}$ & $\begin{array}{l}\text { Chen et al. } \\
\text { [50] }\end{array}$ & 2006 \\
\hline Not stated & $\begin{array}{l}\text { Two centrifugation } \\
\text { techniques }\end{array}$ & None & $\begin{array}{l}\text { Gelatin } \\
\text { hydrogel } \\
\text { microspheres }\end{array}$ & $\begin{array}{l}\text { Less severe histological grading scale and } \\
\text { increased proteoglycan production }\end{array}$ & $\begin{array}{l}\text { Nagae } \\
\text { et al. [53] }\end{array}$ & 2007 \\
\hline $\begin{array}{l}\text { Bovine thrombin ( } 100 \\
\text { IU bovine thrombin/ } \\
150 \mathrm{ml} \mathrm{PRP)}\end{array}$ & $\begin{array}{l}\text { MSC blood cell separation } \\
\text { system (Haemonetics Corp.) }\end{array}$ & None & None & $\begin{array}{l}\text { Significantly increased levels of mRNAs } \\
\text { involved in chondrogenesis and matrix } \\
\text { accumulation; increased disc height index }\end{array}$ & $\begin{array}{l}\text { Chen et al. } \\
\text { [51] }\end{array}$ & 2009 \\
\hline Not stated & $\begin{array}{l}\text { Two centrifugation } \\
\text { techniques }\end{array}$ & None & $\begin{array}{l}\text { Gelatin } \\
\text { hydrogel } \\
\text { microspheres }\end{array}$ & $\begin{array}{l}\text { Increased mRNA expression of proteoglycan } \\
\text { core protein and type II collagen; maintained } \\
\text { disc height and signal intensity on MRI }\end{array}$ & $\begin{array}{l}\text { Sawamura } \\
\text { et al. [54] }\end{array}$ & 2009 \\
\hline Not stated & Not stated & None & None & $\begin{array}{l}\text { Higher fluid content on MRI, reversed or } \\
\text { modified disc height }\end{array}$ & $\begin{array}{l}\text { Gullung } \\
\text { et al. [46] }\end{array}$ & 2011 \\
\hline $\begin{array}{l}\text { Autologous serum and } \\
2 \% \mathrm{CaCl}_{2}\end{array}$ & $\begin{array}{l}\text { Two centrifugation } \\
\text { techniques }\end{array}$ & None & None & $\begin{array}{l}\text { Restored disc height and stimulated MRI T2 } \\
\text { value }\end{array}$ & $\begin{array}{l}\text { Obata } \\
\text { et al. } \\
{[47,48]}\end{array}$ & $\begin{array}{l}2010 \\
2012\end{array}$ \\
\hline $\begin{array}{l}10 \% \text { thrombin solution } \\
(\mathrm{vol} / \mathrm{vol}, 1,000 \mathrm{U} / \mathrm{ml} \text { in } \\
\left.90 \mathrm{mmol} / / \mathrm{CaCl}_{2}\right)\end{array}$ & $\begin{array}{l}\text { Two centrifugation } \\
\text { techniques }\end{array}$ & None & None & $\begin{array}{l}\text { Increased production of extracellular matrix } \\
\text { and maintained MRI signal intensity }\end{array}$ & $\begin{array}{l}\text { Hu et al. } \\
{[49]}\end{array}$ & 2012 \\
\hline
\end{tabular}

The efficacy of PRP has been confirmed by many in vivo and in vitro studies, working via the proliferative effects of multiple growth factors secreted from the platelets. PRP could effectively stimulate the restoration of degenerated discs by promoting cell proliferation and increasing the production of extracellular matrix. $M R I$, magnetic resonance imaging; MSC, mesenchymal stem cell; PRP, platelet-rich plasma.

height index was significantly increased in the PRP regeneration groups.

A study from Akeda and colleagues [52] demonstrated that PRP had a mild stimulatory effect on the proliferation of intervertebral disc cells. The authors concluded that the local administration of PRP might stimulate intervertebral disc repair, and autologous blood would be favored as a source of growth factors needed to stimulate cells for tissue engineering of the intervertebral disc. However, the injected PRP within intervertebral discs might release growth factors in an unstable manner at different rates. To slow the release of biological factors within PRP, Nagae and colleagues [53] used a combination therapy of PRP implanted within gelatin hydrogel microspheres on a rabbit IDD model. The immobilized PRP released PRP-related growth factors in a sustained manner with the degradation of the microspheres, and the degeneration of intervertebral discs was remarkably suppressed over the 8 -week period in the PRP group. The authors suggested that the combined administration of PRP and gelatin hydrogel microspheres may serve as a promising therapeutic strategy for IDD. This study was advanced by Sawamura and colleagues [54], the authors further confirming the efficacy of PRP impregnated within gelatin hydrogel microspheres to retard the degenerative trend. Gullung and colleagues [46] compared the regenerative effects of early PRP injection and delayed PRP injection in a rat IDD model induced by needle puncture of Sprague-Dawley rats. Both early and delayed PRP intervention resulted in higher fluid content on MRI, and the disc was superior in the early PRP injection group. Obata and colleagues [47,48] demonstrated that intra-discal injection of PRP serum was effective for restoring disc height and promoting cell proliferation in a rabbit model, and further held that PRP is safe and immediately available for clinical application. Recently, a study from our group confirmed that a single injection of PRP was potent enough to increase the production of extracellular matrix and maintained the MRI signal intensity of degenerated discs in a rabbit model [49]. All these studies offer a promising option for the regeneration of IDD compared with the traditional, conservative therapies and ultimate surgery, and indicate that PRP could effectively stimulate the restoration of degenerated intervertebral discs via the proliferative effects of multiple growth factors secreted from the platelets.

\section{Possible mechanism of the therapeutic effect of} platelet-rich plasma in intervertebral disc degeneration Platelets have exhibited greater therapeutic potential than ever imagined, releasing growth factors and other 
molecules that help to repair damaged tissues [55]. Over 1,500 proteins are stored within platelets, including growth factors in platelet $\alpha$-granules that have been proven to promote normal healing responses [56,57]. PRP, as a source of concentrated platelets, may help to restore the integrity of the cellular matrix of degenerating discs through the synergistic effects of multiple growth factors.

The balance between decomposition and accumulation determines the integrity and mechanical behavior of discs. Thus, increased extracellular matrix, mainly including aggrecan and collagen, helps to maintain the mechanical functions of the discs. Aggrecan, the major proteoglycan, is rich in negatively charged sulfate and carboxyl groups, contributing to high osmotic pressure for the absorption of water $[19,58,59]$. The increased collagen provides tensile strength and anchors the tissue to the bone [19].

As an aneural and avascular tissue, the intervertebral disc derives nutrients and oxygen from two thin CEPs [60]. During the progression of IDD, the calcification of the CEPs is accompanied by the obliteration of the small blood vessels [61]. This was supposed to be one of the causes of IDD. In degenerating discs, however, blood vessels were found in the endplates and subchondral bone, which may imply that vascularization was strongly associated with tissue repair $[62,63]$. Based on this understanding, VEGF released from PRP is a potent cytokine for vascularization within the CEP, promoting the diffusion of nutrients to the degenerated discs. The synthesis of integrins and interleukins induced by the platelets will spark the inflammatory response and alert immune cells $[43,44]$. As the apoptosis of chondrocytes within the CEP is believed to be an important cause of IDD, PRP-derived growth factors, such as TGF- $\beta$, IGF, and FGF may restore the degenerated CEP by promoting cell growth and tissue regeneration.

Although new vessel formation would help to reestablish nutritive perfusion during the process of wound healing $[64,65]$, the enhanced neovascularization is associated with severe histodegeneration of the discs. Also, the local vascular inflammatory reactions resulting from the synthesis of integrins and interleukins may be the main cause of the painful disc fibrosis and degeneration [66]. Degeneration in discs is associated with increases in the number of nerves and blood vessels [67]. Thus, along with the advantage of better nutrient supply induced by PRP, there is the possible disadvantage of significant pain and calcification through the process of inflammation. Therefore, further studies are still needed to investigate the undesirable effects induced by PRP.

Some studies have indicated that a certain number of mesenchymal stem cells (MSCs) exist in human degenerated intervertebral discs, including the CEP, nucleus pulposus and annulus fibrosus tissues [68-71], although none reported whether PRP affects the proliferation and differentiation of these specialized MSCs. But a study on the influence of PRP on human MSCs has proved that PRP enhanced MSC proliferation and induced chondrogenic differentiation of MSCs in vitro [72]. Stem cells derived from tendon also showed a trend to proliferate and differentiate toward activated tenocytes when cultured with PRP [73]. Therefore, we further propose that PRP, as a growth factor cocktail, might stimulate the differentiation of intervertebral disc MSCs towards mature intervertebral disc cells and upregulate the synthesis of extracellular matrix, and finally slow or reverse the degenerative trend of IDD.

\section{Limitations of the current evidence on the application of platelet-rich plasma therapy and directions of future research}

PRP has demonstrated efficacy when used as a culture supplement for tissue engineering, as well as in promoting the biological regeneration of degenerated intervertebral discs. Currently, most findings indicate that PRP could serve as a potential therapeutic candidate to facilitate biological disc repair. However, some problems need to be resolved before the clinical application of PRP for the treatment of IDD. Currently, the pathological mechanism of IDD is still unclear, and current studies further indicate that a certain number of MSCs inhabit degenerated human nucleus pulposus. So, further studies are required to clarify the impact of PRP on the proliferation and differentiation of the nucleus pulposus-derived stem cells. PRP produced by different procedures may lead to varying degrees of platelet destruction, resulting in different concentrations of growth factors. Furthermore, as no uniform standard has been determined for stable PRP production, quality assurance of PRP should be taken into serious consideration. In addition, the optimal doses of various growth factors in PRP for tissue regeneration and the interactions between the different growth factors remain to be elucidated. Clinical PRP applications are currently focused on maxillofacial tissue engineering while clinical data for PRP therapy in IDD are still insufficient. The mechanism of IDD together with the roles of PRP in treating it are focal points of future research.

\section{Abbreviations}

CEP: Cartilage endplate; CTFG: Connective tissue growth factor;

EGF: Epidermal growth factor; FGF: Fibroblastic growth factor; GDF: Growth and differentiation factor; IDD: Intervertebral disc degeneration; IGF: Insulinlike growth factor; MRI: Magnetic resonance imaging; MSC: Mesenchymal stem cell; PDGF: Platelet-derived growth factor; PRP: Platelet-rich plasma; TGF: Transforming growth factor; VEGF: Vascular endothelial growth factor.

\section{Competing interests}

The authors declare that they have no competing interests. 


\section{Acknowledgements}

This work was supported by National Natural Science Foundation of China (grant no. 81201422), China Postdoctoral Science Foundation (grant no. 2012M520983), National Student Innovation Training Program of China (grant no. 1210286090), Jiangsu Province Science Foundation for Youths (grant no. BK2012334) and Innovative Foundation of Southeast University (grant no. 3290002401).

\section{Author details}

${ }^{1}$ Department of Orthopaedics, Zhongda Hospital, Medical School of Southeast University, 87 Ding Jia Qiao Road, Nanjing, Jiangsu 210009, China ${ }^{2}$ Department of Orthopaedics and Traumatology, Faculty of Medicine, The Chinese University of Hong Kong, Hong Kong SAR, Hongkong, China.

\section{Published: 28 Oct 2013}

\section{References}

1. Frymoyer JW, Cats-Baril WL: An overview of the incidence and costs of low back pain. Orthop Clin North Am 1991, 22:263-271.

2. Shvartzman $L$, Weingarten $E$, Sherry $H$, Levin S, Persaud A: Costeffectiveness analysis of extended conservative therapy versus surgical intervention in the management of herniated lumbar intervertebral disc. Spine 1992, 17:176-182.

3. An HS, Thonar EJ, Masuda K: Biological repair of intervertebral disc. Spine 2003, 28:S86-S92.

4. Evans C: Potential biologic therapies for the intervertebral disc. J Bone Joint Surg Am 2006, 88:95-98

5. Pietrzak WS, Eppley BL: Platelet rich plasma: biology and new technology. J Craniofac Surg 2005, 16:1043-1054.

6. Freemont AJ: The cellular pathobiology of the degenerate intervertebral disc and discogenic back pain. Rheumatology 2009, 48:5-10.

7. Choi YS: Pathophysiology of degenerative disc disease. Asian Spine J 2009, 3:39-44.

8. Schoenfeld AJ, Nelson JH, Burks R, Belmont PJ Jr: Incidence and risk factors for lumbar degenerative disc disease in the United States military 19992008. Mil Med 2011, 176:1320-1324.

9. Singh K, Masuda K, An HS: Animal models for human disc degeneration. Spine J 2005, 5:267S-279S.

10. Adams MA, Roughley PJ: What is intervertebral disc degeneration, and what causes it? Spine 2006, 31:2151-2161.

11. Karppinen J, Shen FH, Luk KD, Andersson GB, Cheung KM, Samartzis D: Management of degenerative disk disease and chronic low back pain. Orthop Clin North Am 2011, 42:513-528.

12. Sakai D: Future perspectives of cell-based therapy for intervertebral disc disease. Eur Spine J 2008, 17:452-458

13. Yoon ST, Patel NM: Molecular therapy of the intervertebral disc. Eur Spine J 2006, 15:S379-S388.

14. Masuda K, An HS: Prevention of disc degeneration with growth factors. Eur Spine J 2006, 15:S422-S432.

15. Crevensten G, Walsh AJ, Ananthakrishnan D, Page P, Wahba GM, Lotz JC, Berven S: Intervertebral disc cell therapy for regeneration: mesenchymal stem cell implantation in rat intervertebral discs. Ann Biomed Eng 2004, 32:430-434

16. Hiyama A, Mochida J, Iwashina T, Omi H, Watanabe T, Serigano K, Tamura F, Sakai D: Transplantation of mesenchymal stem cells in a canine disc degeneration model. J Orthop Res 2008, 26:589-600.

17. Zhang YG, Guo X, Xu P, Kang LL, Li J: Bone mesenchymal stem cells transplanted into rabbit intervertebral discs can increase proteoglycans. Clin Orthop Relat Res 2005, 430:219-226.

18. Lyons G, Eisenstein SM, Sweet MB: Biochemical changes in intervertebral disc degeneration. Biochim Biophys Acta 1981, 673:443-453.

19. Urban JP, Roberts S: Degeneration of the intervertebral disc. Arthritis Res Ther 2003, 5:120-130.

20. Freemont AJ: The cellular pathobiology of the degenerate intervertebral disc and discogenic back pain. Rheumatology 2009, 48:5-10.

21. Yang SH, Lin CC, Hu MH, Shih TT, Sun YH, Lin FH: Influence of age-related degeneration on regenerative potential of human nucleus pulposus cells. J Orthop Res 2010, 28:379-383.

22. Masuda K: Biological repair of the degenerated intervertebral disc by the injection of growth factors. Eur Spine J 2008, 17:441-451.
23. Le Maitre $\mathrm{CL}$, Freemont $\mathrm{AJ}$, Hoyland JA: A preliminary in vitro study into the use of IL-1Ra gene therapy for the inhibition of intervertebral disc degeneration. Int J Exp Pathol 2006, 87:17-28

24. Wallach CJ, Sobajima S, Watanabe Y, Kim JS, Georgescu HI, Robbins P, Gilbertson LG, Kang JD: Gene transfer of the catabolic inhibitor TIMP-1 increases measured proteoglycans in cells from degenerated human intervertebral discs. Spine 2003, 28:2331-2337.

25. Sakai D, Mochida J, Iwashina T, Watanabe T, Nakai T, Ando K, Hotta T: Differentiation of mesenchymal stem cells transplanted to a rabbit degenerative disc model: potential and limitations for stem cell therapy in disc regeneration. Spine 2005, 30:2379-2387.

26. Zhang Y, Drapeau S, Howard SA, Thonar EJ, Anderson DG: Transplantation of goat bone marrow stromal cells to the degenerating intervertebral disc in a goat disc injury model. Spine 2011, 36:372-377.

27. Masuda K, Oegema TR Jr, An HS: Growth factors and treatment of intervertebral disc degeneration. Spine 2004, 29:2757-2769.

28. Nishida K, Kang JD, Gilbertson LG, Moon SH, Suh JK, Vogt MT, Robbins PD, Evans $\mathrm{CH}$ : Modulation of the biologic activity of the rabbit intervertebral disc by gene therapy: an in vivo study of adenovirus-mediated transfer of the human transforming growth factor beta 1 encoding gene. Spine 1999, 24:2419-2425.

29. Osada R, Ohshima H, Ishihara H, Yudoh K, Sakai K, Matsui H, Tsuji H: Autocrine/paracrine mechanism of insulin-like growth factor-1 secretion, and the effect of insulin-like growth factor-1 on proteoglycan synthesis in bovine intervertebral discs. J Orthop Res 1996, 14:690-699.

30. Gruber HE, Fisher EC Jr, Desai B, Stasky AA, Hoelscher G, Hanley EN Jr: Human intervertebral disc cells from the annulus: three-dimensional culture in agarose or alginate and responsiveness to TGF-beta1. Exp Cell Res 1997, 235:13-21.

31. Lee Kl, Moon SH, Kim H, Kwon UH, Kim HJ, Park SN, Suh H, Lee HM, Kim HS, Chun HJ, Kwon IK, Jang JW: Tissue engineering of the intervertebral disc with cultured nucleus pulposus cells using atelocollagen scaffold and growth factors. Spine 2012, 37:452-458

32. Thompson JP, Oegema TR Jr, Bradford DS: Stimulation of mature canine intervertebral disc by growth factors. Spine 1991, 16:253-260.

33. Hayes AJ, Ralphs JR: The response of foetal annulus fibrosus cells to growth factors: modulation of matrix synthesis by TGF- $\beta 1$ and IGF-1. Histochem Cell Biol 2011, 136:163-175.

34. Gruber HE, Norton HJ, Hanley EN Jr: Anti-apoptotic effects of IGF-1 and PDGF on human intervertebral disc cells in vitro. Spine 2000, 25:2153-2157.

35. Pratsinis H, Kletsas D: PDGF, bFGF and IGF-I stimulate the proliferation of intervertebral disc cells in vitro via the activation of the ERK and Akt signaling pathways. Eur Spine J 2007, 16:1858-1866.

36. Fuijta N, Imai J, Suzuki T, Yamada M, Ninomiya K, Miyamoto K: Vascular endothelial growth factor-A is a survival factor for nucleus pulposus cells in the intervertebral disc. Biochem Biophys Res Commun 2008, 372:367-372.

37. Liu Y, Kong J, Chen BH, Hu YG: Combined expression of CTGF and tissue inhibitor of metalloprotease-1 promotes synthesis of proteoglycan and collagen type II in rhesus monkey lumbar intervertebral disc cells in vitro. Chin Med J (Engl) 2010, 123:2082-2087.

38. Walsh AJ, Bradford DS, Lotz JC: In vivo growth factor treatment of degenerated intervertebral discs. Spine 2004, 29:156-163.

39. Marx RE: Platelet-rich plasma (PRP): what is PRP and what is not PRP? Implant Dent 2001, 10:225-228.

40. Sánchez-González DJ, Méndez-Bolaina E, Trejo-Bahena NI: Platelet-rich plasma peptides: key for regeneration. Int J Pept 2012, 2012:532519.

41. Brass L: Understanding and evaluating platelet function. Hematology Am Soc Hematol Educ Program 2010, 2010:387-396.

42. Knighton DR, Hunt TK, Thakral KK, Goodson WH 3rd: Role of platelets and fibrin in the healing sequence: an in vivo study of angiogenesis and collagen synthesis. Ann Surg 1982, 196:379-388.

43. Fréchette JP, Martineau I, Gagnon G: Platelet-rich plasmas: growth factor content and roles in wound healing. J Dent Res 2005, 84:434-439.

44. Leslie M: Cell biology. Beyond clotting: the powers of platelets. Science 2010, 328:562-564.

45. Marx RE: Platelet-rich plasma: evidence to support its use. J Ora Maxillofac Surg 2004, 62:489-496.

46. Gullung GB, Woodall JW, Tucci MA, James J, Black DA, McGuire RA: Plateletrich plasma effects on degenerative disc disease: analysis of histology and imaging in an animal model. Evid Based Spine Care J 2011, 2:13-18. 
47. Obata S, Akeda K, Morimoto R, Asanuma Y, Kasai Y, Masuda K, Uchida A, Sudo A: Intradiscal injection of autologous platelet-rich plasma-serum induces the restoration of disc height in the rabbit anular needle puncture model: 12 [abstract]. Spine Aff Soc Meeting Abstracts 2010, 12

48. Obata S, Akeda K, Imanishi T, Masuda K, Bae W, Morimoto R, Asanuma Y, Kasai Y, Uchida A, Sudo A: Effect of autologous platelet-rich plasmareleasate on intervertebral disc degeneration in the rabbit anular puncture model: a preclinical study. Arthritis Res Ther 2012, 14:R241.

49. Hu X, Wang C: An experimental study on the effect of autologous platelet-rich plasma on treatment of early intervertebral disc degeneration. Zhongguo Xiu Fu Chong Jian Wai Ke Za Zhi 2012, 26:977-983.

50. Chen WH, Lo WC, Lee JJ, Su CH, Lin CT, Liu HY, Lin TW, Lin WC, Huang TY, Deng WP: Tissue-engineered intervertebral disc and chondrogenesis using human nucleus pulposus regulated through TGF-beta1 in plateletrich plasma. J Cell Physiol 2006, 209:744-754.

51. Chen WH, Liu HY, Lo WC, Wu SC, Chi CH, Chang HY, Hsiao SH, Wu CH, Chiu WT, Chen BJ, Deng WP: Intervertebral disc regeneration in an ex vivo culture system using mesenchymal stem cells and platelet-rich plasma. Biomaterials 2009, 30:5523-5533.

52. Akeda K, An HS, Pichika R, Attawia M, Thonar EJ, Lenz ME, Uchida A, Masuda K: Platelet-rich plasma (PRP) stimulates the extracellular matrix metabolism of porcine nucleus pulposus and anulus fibrosus cells cultured in alginate beads. Spine 2006, 31:959-966.

53. Nagae M, Ikeda T, Mikami Y, Hase H, Ozawa H, Matsuda K, Sakamoto H, Tabata Y, Kawata M, Kubo T: Intervertebral disc regeneration using platelet-rich plasma and biodegradable gelatin hydrogel microspheres. Tissue Eng 2007, 13:147-158.

54. Sawamura K, Ikeda T, Nagae M, Okamoto S, Mikami Y, Hase H, Ikoma K, Yamada T, Sakamoto H, Matsuda K, Tabata Y, Kawata M, Kubo T: Characterization of in vivo effects of platelet-rich plasma and biodegradable gelatin hydrogel microspheres on degenerated intervertebral discs. Tissue Eng 2009, 15:3719-3727.

55. Brass L: Understanding and evaluating platelet function. Hematology. Am Soc Hematol Educ Program 2010, 2010:387-396.

56. McNicol A, Israels SJ: Beyond hemostasis: the role of platelets in inflammation, malignancy and infection. Cardiovasc Hematol Disord Drug Targets 2008, 8:99-117.

57. Rozman P, Bolta Z: Use of platelet growth factors in treating wounds and soft-tissue injuries. Acta Dermatovenerol Alp Panonica Adriat 2007, 16:156-165.

58. Johnstone B, Bayliss MT: The large proteoglycans of the human intervertebral disc. Changes in their biosynthesis and structure with age, topography, and pathology. Spine 1995, 20:674-684

59. Urban JP, Maroudas A, Bayliss MT, Dillon J: Swelling pressures of proteoglycans at the concentrations found in cartilaginous tissues. Biorheology 1979, 16:447-464.

60. Urban JP, Smith S, Fairbank JC: Nutrition of the intervertebral disc. Spine 2004, 29:2700-2709.

61. Moore RJ: The vertebral endplate: disc degeneration, disc regeneration. Eur Spine 2006, 15:S333-S337.

62. Brown MF, Hukkanen MVJ, McCarthy ID, Redfern DRM, Batten JJ, Crock HV, Hughes SPF, Polak JM: Sensory and sympathetic innervation of the vertebral endplate in patients with degenerative disc disease. J Bone Joint Surg 1997, 79:147-153.

63. Fagan A, Moore R, Vernon Roberts B, Blumbergs P, Fraser R: The innervation of the intervertebral disc: a quantitative analysis. Spine 2003 , 28:2570-2576

64. Gurtner GC, Werner S, Barrandon Y, Longaker MT: Wound repair and regeneration. Nature 2008, 453:314-321.

65. Folkman J: Fundamental concepts of the angiogenic process. Curr Mol Med 2003, 3:643-651.

66. Peng BG: Pathophysiology, diagnosis, and treatment of discogenic low back pain. World J Orthop 2013, 4:42-52.

67. David G, Ciurea AV, lencean SM, Mohan A: Angiogenesis in the degeneration of the lumbar intervertebral disc. J Med Life 2010, 3:154-161.

68. Liu LT, Huang B, Li CQ, Zhuang Y, Wang J, Zhou Y: Characteristics of stem cells derived from the degenerated human intervertebral disc cartilage endplate. PLoS One 2011, 6:e26285.

69. Henriksson H, Thornemo M, Karlsson C, Hägg O, Junevik K, Lindahl A, Brisby $\mathrm{H}$ : Identification of cell proliferation zones, progenitor cells and a potential stem cell niche in the intervertebral disc region: a study in four species. Spine 2009, 34:2278-2287.
70. Blanco JF, Graciani IF, Sanchez-Guijo FM, Muntión S, Hernandez-Campo P, Santamaria C, Carrancio S, Barbado MV, Cruz G, Gutierrez-Cosío S, Herrero C, San Miguel JF, Briñon JG, del Cañizo MC: Isolation and characterization of mesenchymal stromal cells from human degenerated nucleus pulposus: comparison with bone marrow mesenchymal stromal cells from the same subjects. Spine 2010, 35:2259-2265.

71. Risbud MV, Guttapalli A, Tsai T, Lee JY, Danielson KG, Vaccaro AR, Albert TJ, Gazit Z, Gazit D, Shapiro IM: Evidence for skeletal progenitor cells in the degenerate human intervertebral disc. Spine 2007, 32:2537-2544.

72. Mishra A, Tummala P, King A, Lee B, Kraus M, Tse V, Jacobs CR: Buffered platelet-rich plasma enhances mesenchymal stem cell proliferation and chondrogenic differentiation. Tissue Eng 2009, 15:431-435.

73. Zhang J, Wang JH: Platelet-rich plasma releasate promotes differentiation of tendon stem cells into active tenocytes. Am J Sports Med 2010, 38:2477-2486

10.1186/ar4353

Cite this article as: Wang et al.: Enhancing intervertebral disc repair and regeneration through biology: platelet-rich plasma as an alternative strategy. Arthritis Research \& Therapy 2013, 15:220 